\section{3 総括}

（1）QAS の起ホウ力は陽イオンの化学構造に影響 されず, 陰イオンの影響が大きく, 過塩素酸塩, 安息香 酸塩, パラトルエンスルホン酸塩が特にすぐれている。

（2）分散力は, 陰イオンが安息香酸基およびパラト ルェンスルホン酸基である QAS と, 陽イオンの親油基 にベンゼン核，エーテル基を含む QAS が特にすぐれて いる。

（3）静菌力は陰イオンによって変わらない。

終わりに本研究の発表を許可下さいました当社関係各位およ び静菌力のご指導を賜わった大阪大学薬学部川崎教授, 岡田助
手に深謝します。

昭和 37 年 12 月 8 日油化学討論会および昭和 37 年 11 月 23 日関西薬学会で発表。 （昭和 38 年 3 月 29 日受理）

\section{文献}

1) 山本, 山田, 角田, 難波, 本誌, 11, 298 (1962)

2) 山本, 角田, 難波, 本誌, 11，369 (1962)

3）山本，角田，難波，本誌，11，646 (1962)

4) 日化年会 (1959) で発表

5) A.M. Mankowich, Ind. Eng. Chem., 44, 1151 (1952)

6) Klevens. J. Am. Oil Chemists' Soc., 30, 74 (1953)

7) C.A. Lawrence, "Surface-Active Quaternary Ammonium Germicides"' (1950); Academic Press, New York

8）青木, 岩山, 薬誌, 79, 522 (1959)

\section{統計}

\section{油脂製品生産統計（その 2)}

野 中 正 夫

昭和 37 年界面活性剂等生産実績

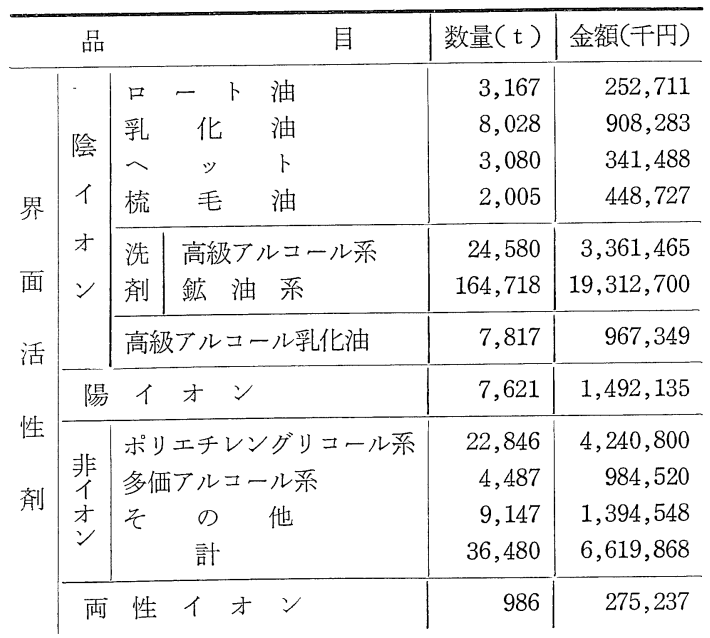

昭和 37 年界面活性剂需要別出荷実績

\begin{tabular}{|c|c|c|c|c|c|c|c|c|}
\hline 途 & 繊 維 & 農林業 & 紙パルプ & 金 属 & $\begin{array}{l}\text { 医薬・ } \\
\text { 香 精 }\end{array}$ & 家庭用 & その他 & 合 計 \\
\hline 陰イオン界面活性剂 & 41,698 & 854 & 1,431 & 2,158 & 1,112 & 137,849 & 19,820 & 204,922 \\
\hline 陽イオン界面活性剂 & 3,990 & 110 & 12 & 78 & 357 & - & 905 & 5,452 \\
\hline 非イオン界面活性剂 & 20,099 & 2,212 & 2,071 & 1,011 & 727 & 548 & 4,199 & 30,867 \\
\hline 両性界面活性剂 & 887 & 31 & 35 & 20 & 46 & - & 115 & 1,134 \\
\hline その他の 助 剂 & 3,496 & 217 & 309 & 1,234 & 35 & - & 895 & 6,186 \\
\hline 計 & 70,170 & 3,424 & 3,858 & 4,501 & 2,277 & 138,397 & 25,934 & 248,561 \\
\hline
\end{tabular}

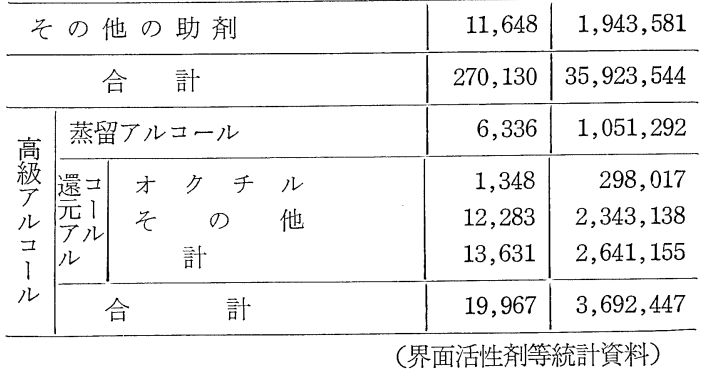

昭和 37 年界面活性剂イオン別生産実績 （単位 t )

\begin{tabular}{|c|c|c|}
\hline 陰イオン & $\begin{array}{l}\text { 陰イオン（合成洗剤を除く） } \\
\text { 合 成 洗 成 } \\
\text { 小 計 }\end{array}$ & $\begin{array}{r}24,097 \\
189,298 \\
213,395\end{array}$ \\
\hline 陽 イ & ע & 7,621 \\
\hline 非 イ & ע & 36,480 \\
\hline 両 & 性 & 986 \\
\hline その他の & & 11,648 \\
\hline \multicolumn{2}{|l|}{ 計 } & 270,130 \\
\hline
\end{tabular}

(単位 $\mathrm{t}$ ) 昭和 37 年家庭用合成洗侴生産実績（単位 $\mathrm{t}$ )

\begin{tabular}{|c|c|c|c|c|}
\hline 形＼cjkstart状＼cjkstart別 & 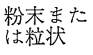 & 液 体 & その他 & 計 \\
\hline 鉱 油 系 & 98,481 & 18,360 & 16 & 116,857 \\
\hline $\begin{array}{l}\text { 高級アルコー } \\
\text { ル系 }\end{array}$ & 9,352 & 2,070 & 899 & 12,321 \\
\hline 非イオン系 & 2,097 & 1,010 & 5 & 3,112 \\
\hline その他 & - & 226 & 5 & 231 \\
\hline 計 & 109,930 & 21,666 & 925 & 132,521 \\
\hline
\end{tabular}

